\title{
Study of Phase Evolution in Sputtered Al/Ru Bi-layers Nanocrystalline Thin Films
}

\author{
I. K. El Zawawi ${ }^{1}$, E.M. Abdelrazek ${ }^{2}$, F. A. Saadallah', B. Mansour ${ }^{1}$, \\ M. Ebrahim ${ }^{1}$. F. Muecklich ${ }^{3}$, C. Holzapfel ${ }^{3}$, H. A. Gobran ${ }^{3}$ \\ 1) Solid State Physics Department, National Research Centre, Cairo, \\ Egypt. \\ 2) Experimental Physics Department, Faculty of Science, Mansoura \\ University, Mansoura, Egypt \\ ${ }^{3)}$ Department for Materials Science, Saarland University, Saarbrücken, \\ Germany
}

Physical vapor deposited Al/Ru bi-layers on silicon substrates have been annealed to study reactions development. Temperature induced changes after increasing time from 10 to $2880 \mathrm{~min}$ in vacuum annealing at $500{ }^{\circ} \mathrm{C}$ were studied. Grazing incidence X-ray Diffraction indicates $R u A l_{2}$ phase formation in all samples. Electron diffraction pattern of a thin foil extracted from annealed bilayers shows spots for $\mathrm{RuAl}_{2}$ and $\mathrm{Al}_{6} \mathrm{Ru}$ phases. Focused ion beam cross sections, shows non-uniform $500 \mathrm{~nm}$ thickness reaction layer at the $A l / R u$ interface. Decreasing thickness at a fixed ratio of $\mathrm{Ru} / \mathrm{Al}=1.224$ reduces the time required to start reaction at the same temperature. Formed intermetallic phase layer acts as a diffusion barrier that controls further atomic diffusion from both $\mathrm{Al}$ and $\mathrm{Ru}$ sides into the formed reaction layer.

\section{Introduction:}

$\mathrm{Ru} / \mathrm{Al}$ system contains intermetallic compounds as $\mathrm{RuAl}$, which has attractive properties, like structural, high temperature oxidation resistance, good mechanical properties and aqueous corrosion resistance in some very aggressive environments [1]. Also, $\mathrm{Al}_{6} \mathrm{Ru}$ has quasicrystalline [2] and $\mathrm{RuAl}_{2}$ has semiconducting behaviors [3]. This motivates the research in intermetallic thin films because of the high surface to thickness ratio that insures large-scale usage of their properties. The known $\mathrm{Al} / \mathrm{Ru}$ binary phase diagram exhibits bulk materials equilibrium state of reactions that is different from nanocrystalline non-equilibrium state, such as thin film alloys and coatings. There is no publication reported in the $\mathrm{Al} / \mathrm{Ru}$ system about first interfacial phase formed between thin film layers, thermodynamic data and the temperature at which the reaction starts. Previous work made on platinum-group alumenides like $\mathrm{Al} / \mathrm{Fe}$, $\mathrm{Al} / \mathrm{Ni}$ thin films, indicates $\mathrm{FeAl}_{3}$ formation at $625{ }^{\circ} \mathrm{C}$ at the interfacial contact [4] in $\mathrm{Al} / \mathrm{Fe}$ multilayers contrary to Bene's rule $[5,6]$, which predicts that first 
phase nucleating in such structures is that neighbor to the low temperature eutectic in the binary phase diagram, i.e., to the $\mathrm{Al}$ side. The $\mathrm{Al}_{3} \mathrm{Ni}$ intermetallic phase formation in $\mathrm{Al} / \mathrm{Ni}$ multilayers at $160^{\circ} \mathrm{C}$ confirms Bene's rule. Thermodynamic considerations on the basis of the free energy differences $\Delta \mathrm{G}$ $[7,8]$ favor always the formation of $\mathrm{AlNi}$ in $\mathrm{Al} / \mathrm{Ni}$ system and not $\mathrm{Al}_{3} \mathrm{Ni}$. The phases $\mathrm{FeAl}_{3}, \mathrm{Fe}_{2} \mathrm{Al}_{5}$ and $\mathrm{FeAl}_{2}\left(\Delta \mathrm{H}=-27.9 \mathrm{~kJ} \mathrm{~mol}^{-1}\right),\left(\Delta \mathrm{H}=-27.0 \mathrm{~kJ} \mathrm{~mol}^{-1}\right)$, and $\left(\Delta \mathrm{H}=-26.1 \mathrm{~kJ} \mathrm{~mol}^{-1}\right)$ respectively, having quite similar values of the heat of formation to that of the body centered phase (B2), $\left(\Delta \mathrm{H}=-25.1 \mathrm{~kJ} \mathrm{~mol}^{-1}\right)$ [9], which forms first, while thermodynamic considerations favor $\mathrm{FeAl}_{3}$ phase formation. Therefore the thermodynamic driving forces derived from equilibrium diagrams are not suitable to explain the observed phase evolution in nanocrystalline systems like $\mathrm{Al} / \mathrm{Ni}$ and $\mathrm{Al} / \mathrm{Fe}$. In this work the interfacial reaction exists in the nanocrystalline $\mathrm{Ru} / \mathrm{Al}$ thin films prepared by $\mathrm{DC}$ magnetron sputtering technique was studied.

\section{Experimental:}

DC magnetron sputtering system used to sputter the $\mathrm{Al} / \mathrm{Ru}$ bi-layer thin films with the detailed preparation parameters shown in Table (1). Different individual layer thicknesses at constant ratio of $\mathrm{d}(\mathrm{Al}) / \mathrm{d}(\mathrm{Ru}) \approx 1.224$ equals the atomic densities ratio between $\mathrm{Al}$ and $\mathrm{Ru}$ to reach 1:1 atomic percent of $\mathrm{Al}$ to $\mathrm{Ru}$ in the reaction zone. $\mathrm{Ru} / \mathrm{Al}$ bi-layers were sputtered on single crystal $\mathrm{Si}$ substrates on (004) plane orientation at temperature of $74{ }^{\circ} \mathrm{C}$ during sputtering, and constant Ar flow and ion beam energies shown in Table (1). The Al layer was first sputtered on the Si substrate to insure good adhesion to the substrate and helping $\mathrm{Ru}$ add atoms diffusion inside $\mathrm{Al}$ layer. The chosen methods to investigate $\mathrm{Al} / \mathrm{Ru}$ bi-layers were able to show interfacial reaction zone development and phase analysis. Therefore, we have used focused ion beam (FIB) tool to cut away (mill) material from a defined area with dimensions typically in square microns [10]. Firstly, we have deposited platinum material onto the surface to protect surface damage, while cutting using concentrated ions and electrons beams. Secondly, Milling is achieved by accelerating concentrated gallium ions to a specific site, which etches off any exposed material, leaving a very clean hole or surface. By introducing inert gases, the FIB can selectively etch one material much faster than surrounding materials, or deposit a metal or oxide.

Phase analysis were made using $\mathrm{X}$-ray diffraction in the grazing incidence (GIXRD) mode at $1^{\circ}$, which depends on reduced penetration depth resulted from small angle incidence of the x-ray beam. While diffraction can happen at the near surface layer or at the interfacial zone, that intermetallic phase formation can be detected by using grazing incidence technique [11]. Electron diffraction and transmission electron microscope (TEM) give us phase 
analysis of the resulted intermetallic phases at different points in the reaction zone. Annealing treatments were made at constant temperature of $500{ }^{\circ} \mathrm{C}$ for different annealing times, where lower annealing temperatures have no effect on the reaction and higher temperatures cause thermal stresses on samples surfaces, which causes thin film cracking and sample damage.

Table (1): DC sputtered parameters of the bi-layer thin films at constant thickness ratio $\approx 1.224$, pressure $=3 \times 10^{-3} \mathrm{~m}$. bar, Ar. flow $=80 \mathrm{Sccm}$ and energy $=100$ Watt.

\begin{tabular}{|c|c|c|c|c|c|}
\hline Sample & Metal & $\begin{array}{c}\text { Sputtering } \\
\text { rate }(\mathrm{nm} / \mathrm{min})\end{array}$ & $\begin{array}{c}\text { Sputtering } \\
\text { time }(\mathrm{sec})\end{array}$ & $\begin{array}{c}\text { Sputtering } \\
\text { temp. }\left({ }^{\circ} \mathrm{C}\right)\end{array}$ & $\begin{array}{c}\text { Thickness } \\
(\mathrm{nm})\end{array}$ \\
\hline \hline Thick bi-layers & $\mathrm{Al}$ & 12 & 5702 & 74 & 1150 \\
S2 & $\mathrm{Ru}$ & 15.7 & 3600 & 74 & 940 \\
\hline Thin bi-layers & $\mathrm{Al}$ & 12 & 1425 & 45 & 287 \\
S3 & $\mathrm{Ru}$ & 15.7 & 900 & 45 \\
\hline
\end{tabular}

\section{Results and Discussion:}

\subsection{Phase Analysis (XRD):}

X-ray diffraction (GIXRD) experiments for $\mathrm{Al} / \mathrm{Ru}$ bi-layers sputtered on single crystal Si substrates at $1^{\circ}$ grazing incidence angle shows no phase change until annealing temperature of less than $500{ }^{\circ} \mathrm{C}$ for $45 \mathrm{~min}$. At $500{ }^{\circ} \mathrm{C}$ for 45 min, $\mathrm{RuAl}_{2}$ can be identified with the GIXRD patterns [12]. Annealed bi-layers at

$500{ }^{\circ} \mathrm{C}$ of (S3) thin film bi-layers shows a small increase in intensities of (111), (202) and (004) planes of orthorhombic unit cell for increasing times from 18 to 2880 minutes in $6 \times 10^{-5}$ mbar vacuum atmosphere. As shown in Fig. (1) the small intensity increase can be due to small amount of phase formation mainly at the interface, because of fast grain boundary diffusion, and short penetration depth of X-rays. Therefore, grazing incidence X-ray diffraction is not the best method to analyze the phases in between the bi-layers. The GIXRD was used with transmission electron microscope (TEM) to analyze a foil from this reaction zone.

\subsection{Transmission Electron Microscope (TEM):}

A foil of approximately $100 \mathrm{~nm}$ thick was extracted from (S2) sample after annealing at $500{ }^{\circ} \mathrm{C}$ for 45 minutes using focused ion beam technique (FIB) for TEM analysis [10]. The foil dark field image of the reaction zone shows non-uniform reaction zone formation of about $500 \mathrm{~nm}$ thickness, due to high surface roughness of the aluminum layer. Reaction layer morphology as shown in Fig. 2(c) had an equiaxed and regular shape grain structures in the 
reaction zone in one region and lamellar grain growth adjacent to the $\mathrm{Ru}$ layer. This regular shape grains belongs to the $\mathrm{Al}_{6} \mathrm{Ru}$ intermetallic phase that has an orthorhombic structure in annealed $\mathrm{Al}$ rich alloys at high temperatures [13]. The other grains belong to the $\mathrm{RuAl}_{2}$ intermetallic phase formed near the $\mathrm{Ru}$ layer interface because it may be the first formed phase. Also, electron diffraction pattern results of the inter-planer spacing matching indicating $\mathrm{Al}_{6} \mathrm{Ru}$ [14] and $\mathrm{RuAl}_{2}$ intermetallic phases with other unmatched $\mathrm{d}$-spacing values, due to unstable phases.
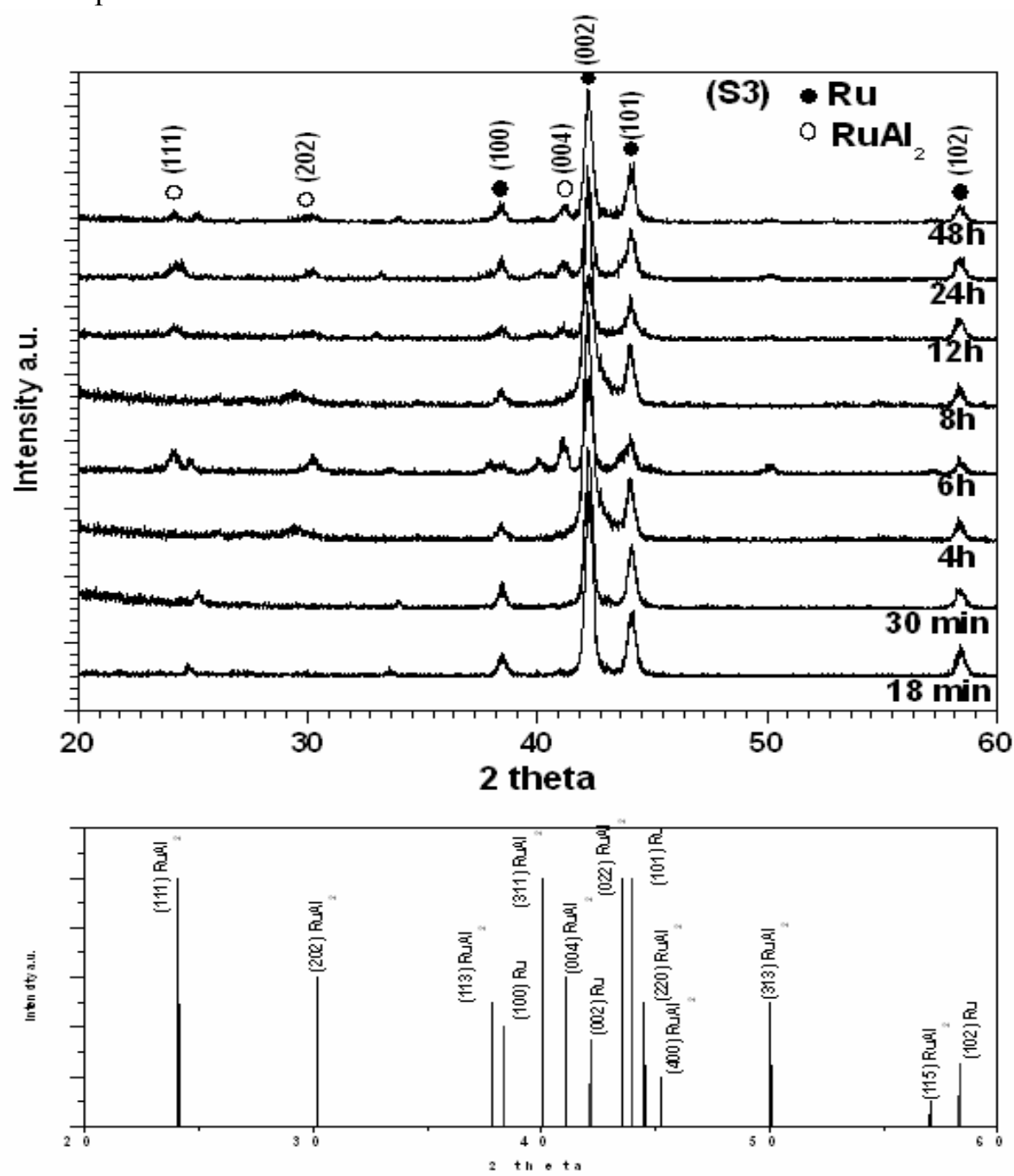

Fig. (1): Grazing incidence X-ray diffraction patterns for annealed S3 sample at $500{ }^{\circ} \mathrm{C}$ at increasing time in hours. 

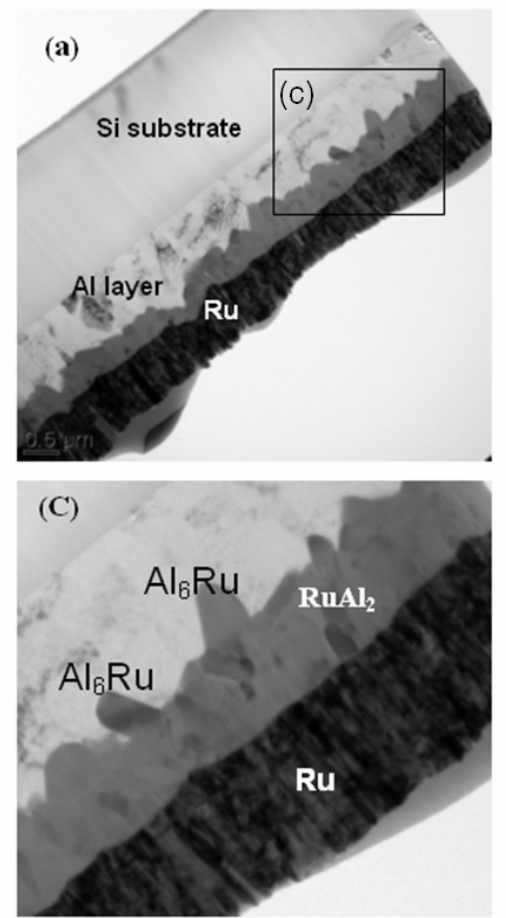

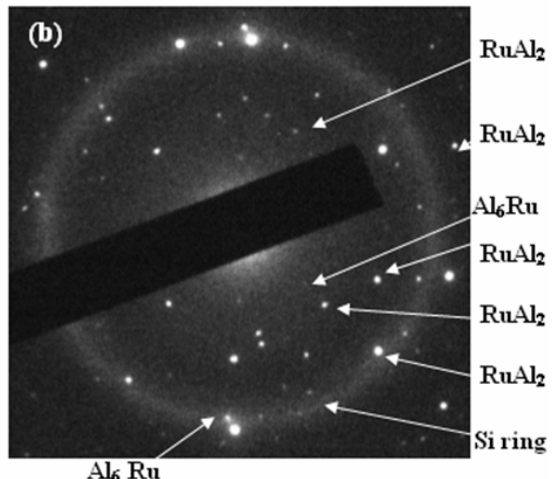

$\mathrm{Al}_{6} \mathrm{Ru}$

Fig. (2). TEM foil dark field image of thick bi-layer S2 sample:

(a) Dark field image of TEM foil extracted with FIB technique.

(b) Electron diffraction pattern obtained through a spot in the reaction zone.

(c) Shows a mgnefied part (black square) from Fig. (2a).

\subsection{Focused Ion Beam (FIB) and Reaction zone kinetics:}

Annealing of bi-layers (S2 samples) as listed in Table (2) at temperatures of $180{ }^{\circ} \mathrm{C}$ and $300{ }^{\circ} \mathrm{C}$ for 45 minutes showed no reaction at the interface between $\mathrm{Al}$ and $\mathrm{Ru}$ bi-layers as shown in Fig. (3a, b). While increasing annealing temperature to $500{ }^{\circ} \mathrm{C}$ for the same time $(45 \mathrm{~min})$ resulted in a nonuniform reaction zone of approximately $500 \mathrm{~nm}$ thickness because of the nonuniform surface topography of sputtered $\mathrm{Al}$ and Ru bi-layers and the texture formed in certain planes during reaction zone growth is shown in Fig. 3(c). Decreasing bi-layers total thickness at the same thickness ratio to the thin bilayers (S3 samples) as listed in Table (1), resulted in a reaction zone at same annealing temperature of $500{ }^{\circ} \mathrm{C}$ after shorter time of 10 minutes as shown in Fig. 3(d). Therefore, to reveal the reaction zone growth mechanism at constant temperature of $500{ }^{\circ} \mathrm{C}$, the effect of bi-layers total thickness and increasing annealing time were studied by making further FIB cross sections in the annealed thin $\mathrm{Al} / \mathrm{Ru}$ bi-layers (sample S3) for times in the range from 10 minutes to 2880 minutes as shown in Fig. (3). 

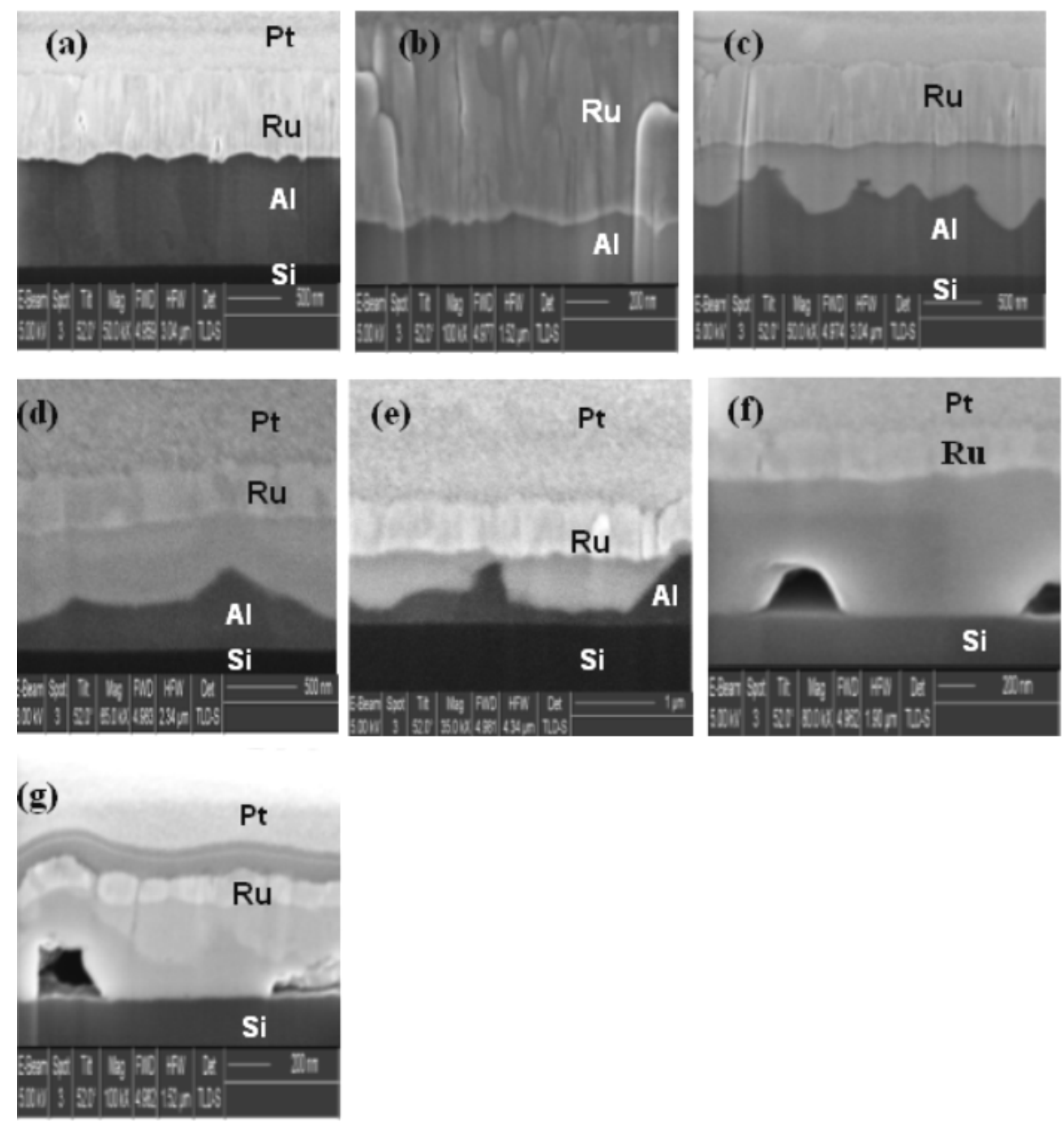

Fig. (3). FIB cuts in annealed bi-layers S2 and S3 samples.
(a) $\mathrm{S} 2$ sample at $180^{\circ} \mathrm{C}$ for $45 \mathrm{~min}$.
(b) $\mathrm{S} 2$ sample at $300^{\circ} \mathrm{C}$ for $45 \mathrm{~min}$.
(c) $\mathrm{S} 2$ sample at $500^{\circ} \mathrm{C}$ for $45 \mathrm{~min}$.
(d) $\mathrm{S} 3$ sample at $500^{\circ} \mathrm{C}$ for $10 \mathrm{~min}$.
(e) $\mathrm{S} 3$ sample at $500^{\circ} \mathrm{C}$ for $18 \mathrm{~min}$.
(f) $\mathrm{S} 3$ sample at $500^{\circ} \mathrm{C}$ for $30 \mathrm{~min}$
(g) $\mathrm{S} 3$ sample at $500^{\circ} \mathrm{C}$ for $2880 \mathrm{~min}$. 
Table (2): Data of sputtered samples of different thicknesses, with different heat treatment conditions and pressure $=6 \times 10^{-6} \mathrm{~m}$.bar. (X-ray diffraction phase analysis from ICDD - CARD No. 19-0045).

\begin{tabular}{|c|c|c|c|c|c|}
\hline Sample & $\begin{array}{l}\text { Anneal. } \\
\text { Time } \\
\text { (min) }\end{array}$ & Elements & $\begin{array}{c}\text { Metal } \\
\text { Thickness } \\
(\mathrm{nm})\end{array}$ & $\begin{array}{l}\text { Anneal. } \\
\text { Temp. } \\
\left({ }^{\circ} \mathrm{C}\right)\end{array}$ & $\begin{array}{c}\text { Reaction } \\
\text { developmen } \\
\mathrm{t}\end{array}$ \\
\hline \multirow{6}{*}{$\begin{array}{l}\text { Thick bi-layers } \\
\text { S2 }\end{array}$} & \multirow{2}{*}{45} & $\mathrm{Al}$ & 1150 & \multirow{2}{*}{180} & \multirow{2}{*}{ No. reaction } \\
\hline & & $\mathrm{Ru}$ & 940 & & \\
\hline & \multirow{2}{*}{45} & $\mathrm{Al}$ & 1150 & \multirow{2}{*}{300} & \multirow{2}{*}{ No. reaction } \\
\hline & & $\mathrm{Ru}$ & 940 & & \\
\hline & \multirow{2}{*}{45} & $\mathrm{Al}$ & 1150 & \multirow{2}{*}{500} & \multirow{2}{*}{$\mathrm{RuAl}_{2}$} \\
\hline & & $\mathrm{Ru}$ & 940 & & \\
\hline \multirow{16}{*}{$\begin{array}{c}\text { Thin bi-layer } \\
\text { S3 }\end{array}$} & \multirow{2}{*}{10} & $\mathrm{Al}$ & 287 & \multirow{2}{*}{500} & \multirow{2}{*}{$\mathrm{RuAl}_{2}$} \\
\hline & & $\mathrm{Ru}$ & 235 & & \\
\hline & \multirow{2}{*}{18} & $\mathrm{Al}$ & 287 & \multirow{2}{*}{500} & \multirow{2}{*}{$\mathrm{RuAl}_{2}$} \\
\hline & & $\mathrm{Ru}$ & 235 & & \\
\hline & \multirow{2}{*}{30} & $\mathrm{Al}$ & 287 & \multirow{2}{*}{500} & \multirow{2}{*}{$\mathrm{RuAl}_{2}$} \\
\hline & & $\mathrm{Ru}$ & 235 & & \\
\hline & \multirow{2}{*}{120} & $\mathrm{Al}$ & 287 & \multirow{2}{*}{500} & \multirow{2}{*}{$\mathrm{RuAl}_{2}$} \\
\hline & & $\mathrm{Ru}$ & 235 & & \\
\hline & \multirow{2}{*}{240} & $\mathrm{Al}$ & 287 & \multirow{2}{*}{500} & \multirow{2}{*}{$\mathrm{RuAl}_{2}$} \\
\hline & & $\mathrm{Ru}$ & 235 & & \\
\hline & \multirow{2}{*}{360} & $\mathrm{Al}$ & 287 & \multirow{2}{*}{500} & \multirow{2}{*}{$\mathrm{RuAl}_{2}$} \\
\hline & & $\mathrm{Ru}$ & 235 & & \\
\hline & \multirow{2}{*}{480} & $\mathrm{Al}$ & 287 & \multirow{2}{*}{500} & \multirow{2}{*}{$\mathrm{RuAl}_{2}$} \\
\hline & & $\mathrm{Ru}$ & 235 & & \\
\hline & \multirow{2}{*}{2880} & $\mathrm{Al}$ & 287 & \multirow{2}{*}{500} & \multirow{2}{*}{$\mathrm{RuAl}_{2}$} \\
\hline & & $\mathrm{Ru}$ & 235 & & \\
\hline
\end{tabular}

The average of different measured thicknesses along reaction zone FIB cross sections were taken as a measure of the reaction zone thickness at every annealed S3 sample because of non-uniform reaction zone thickness. All measurements were carried out using dual beam workstation (Strata 235, EFI) software in nanometer range. The observation had shown that, the reaction zone thickness increases with increasing annealing time from 10 to approx $120 \mathrm{~min}$ at constant temperature of $500{ }^{\circ} \mathrm{C}$ as shown in Fig. (4). The measured $\mathrm{Al}$ layer thickness decreases sharply and after 30 min nearly totally consumed and very little $\mathrm{Ru}$ contribution to the reaction zone. The $\mathrm{Ru}$ layer shows no further decrease in thickness with increasing annealing time and the reaction zone thickness increases no more. it may be a stable bi-layer of $\mathrm{Ru}$ plus a reaction 
zone after $120 \mathrm{~min}$ at $500{ }^{\circ} \mathrm{C}$ has formed and showing nearly horizontal region with time increase. Observed voids formation on the reaction zone Si substrate interfacial contact are due to unit cell volume variation of intermetallic phases formation observed as in Fig. (3g).

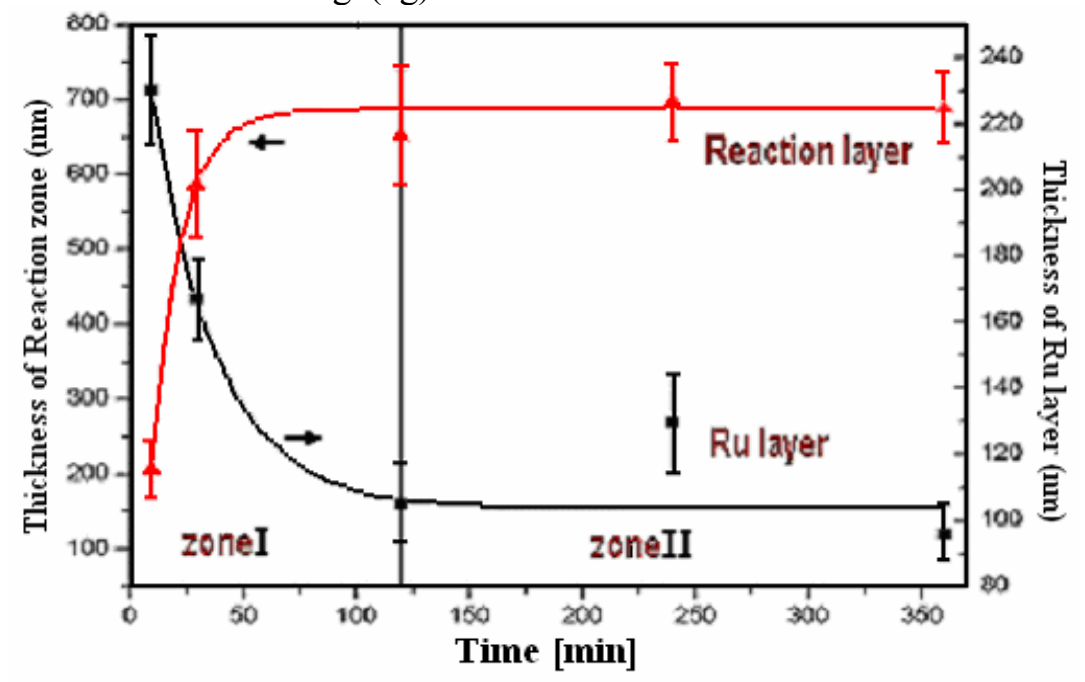

Fig. (4). Reaction zone kinetics.

The relation between annealing time versus the reaction zone and $\mathrm{Ru}$ layer thickness is shown in Fig. (4), which can be divided into two zones (I, II) corresponding to annealing time from (10 to $360 \mathrm{~min}$ ). Zone I can be characterized by the following two processes $\mathrm{I}(1)$ and $\mathrm{I}(2)$. In process $\mathrm{I}(1)$ Aluminum layer thickness is nearly consumed after $30 \mathrm{~min}$ of annealing and the diffusion process is still in progress as shown FIB cross section of Fig.3(e). During process I(2) Unstable intermetallic phases can be formed which are characterized by TEM and XRD. In zone II other processes takes place II(1) and $\mathrm{II}(2)$. In II(1) which the diffusion stops and no more Al material exists in the thin films for further reaction to happen with increasing time. Also, the Ru layer contributes no more in the diffusion reaction and the reaction zone growth stops. In II(2) Stable intermetalic phases have been formed.

\subsection{Effect of layer thickness on the reaction layer kinetics:}

$\mathrm{Al}$ and $\mathrm{Ru}$ individual layer thicknesses play an important role in the phase evolution in the interfacial region. Individual layer thickness determines how long time required for a diffusion-controlled reaction to cover a defined zone length, and the temperature required to start the reaction. The annealing time has been found to be directly proportional to the $\mathrm{Ru} / \mathrm{Al}$ layer thickness at constant temperature. The reaction temperature was $500^{\circ} \mathrm{C}$ for $45 \mathrm{~min}$ in the $\mathrm{Ru} / \mathrm{Al}$ bi-layers of $1150 \mathrm{~nm} \mathrm{Al,} 940 \mathrm{~nm} \mathrm{Ru}$ thick nesses (thick bi-layers) and 
$500^{\circ} \mathrm{C}$ for $10 \mathrm{~min}$ in bi-layers of $287.5 \mathrm{~nm} \mathrm{Al}$ and $235 \mathrm{~nm} \mathrm{Ru}$ (thin bi-layers) thin films. Measured reaction zone thickness \% of the total thickness of the two layers $\mathrm{Al}$ and $\mathrm{Ru}$ decreases from $39.2 \%$ to $27.8 \%$ when the total thickness of both layers increase from thin to thick bi-layers at constant $\mathrm{Ru} / \mathrm{Al}$ thickness ratio. The reaction zone thickness is decreased when the total thickness layer is larger at constant temperature. This due to dependent on the melting point depression of thinner thicknesses at the early stages of nucleation grain sizes. In other words, the smaller a nanostructure grains is the lower melting temperature [15].

The results can be discussed on the basis of the differences between bulk polycrystalline and thin film materials cases, since the resultant phases after annealing are different. In bulk $\mathrm{Al} / \mathrm{Ru}$ system the equilibrium solubility of $\mathrm{Ru}$ and $\mathrm{Al}$ was determined using alloys, which had been annealed for 50 hours at $650^{\circ} \mathrm{C}$ and quenched in water. Also, the equilibrium solubility of $\mathrm{Ru}$ in $\mathrm{Al}$ did not exceed $0.1 \mathrm{wt} \% \mathrm{Ru}$ and in alloys cooled from $1400^{\circ} \mathrm{C}$ at $10^{6} \mathrm{Deg} / \mathrm{sec}$, the variation in the lattice parameters as a function of composition indicates that the solubility in the solid solution increases linearly up to $11.1 \mathrm{wt} \% \mathrm{Ru}$ $[16,17]$. While in $\mathrm{Ru} / \mathrm{Al}$ thin films the reaction can happen at lower temperature $500^{\circ} \mathrm{C}$ at a rate of heating and cooling of $2^{\circ} \mathrm{C} / \mathrm{min}$ for short annealing times $(10$ $\mathrm{min}$ ) as shown in the focused ion beam cross sections in Fig. 3(c).

From the last reaction zone kinetics depicted in Fig. (4), we can see that the reaction zone grows more on the account of Al layers than on the $\mathrm{Ru}$ layer as shown in Fig. 3(f). This was due to higher solubility of aluminum in $\mathrm{Ru}$, meanwhile the $\mathrm{Ru}$ has a maximum solubility of $14 \mathrm{wt} \%$ in $\mathrm{Al}$ under nonequilibrium thermodynamic conditions [16], which are generally applied in nanocrystalline thin films. The diffusion controlled reaction layer forms a diffusion barrier, which controls further diffusion from both $\mathrm{Al}$ and $\mathrm{Ru}$ sides. Therefore, the $\mathrm{Al}$ atoms seem to be the main moving atoms inside the reaction zone. Meanwhile, the $\mathrm{Ru}$ atoms contributing less in the diffusion process until annealing time ends. This can be concluded from the thickness comparison of both layers after long time annealing shown in Fig. 3(f). The matched planes were belonging to $\mathrm{RuAl}_{2}$ and $\mathrm{Al}_{6} \mathrm{Ru}$. The non-uniform reaction zone thickness formation has different reasons. Firstly may be due to non-uniform surface topography of sputtered aluminum layers or high surface roughness, due to insufficient pressure during sputtering. Secondly, the non-uniform thickness formation could be due to induced grain boundary diffusion along certain crystallographic planes because of textured growth of both $\mathrm{Al}$ and $\mathrm{Ru}$ layers after sputtering, which is a normal feature in thin film growth [18] as can be seen from reaction layer morphology in Fig. (2a). 


\section{Conclusion:}

DC magnetron sputtering technique is cabable to produce $\mathrm{Al} / \mathrm{Ru}$ bi-layers of different thicknesses at nearly room temperature. Annealing at $500^{\circ} \mathrm{C}$ for short time $(10 \mathrm{~min})$ is enough to produce intermetallic compounds between $\mathrm{Al}$ and $\mathrm{Ru}$ bi-layers thin films. Increasing annealing times from 10 minutes to 2880 minutes increases the reaction zone thicknesses on the account of the Al layer more than the $\mathrm{Ru}$ layer. Reaction layer contains mainly $\mathrm{RuAl}_{2}$ and $\mathrm{Al}_{6} \mathrm{Ru}$ intermetallic compounds, those are important intermetallics in industry. Reactions of $\mathrm{Al} / \mathrm{Ru}$ nanocrystalline thin films of small thicknesses are different from bulk materials, because reactions starts at lower temperatures for short times of annealing which consumes energy and costs less than in the bulk case. A1/Ru thin film thickness increase at constant thickness ratio has a pronounced effect on the formed intermetallic compound layer thickness at the contact interface. The diffusion at the contact interface had stopped after certain time of annealing, because of the $\mathrm{RuAl}_{2}$ and $\mathrm{Al}_{6} \mathrm{Ru}$ intermetallic phases formation, which controls further diffusion from both sides into the reaction layer.

\section{Acknowledgments:}

We wish to acknowledge the expert microscopy work performed by both C. Holzapfel of Department for Functional Materials research group of Prof. Dr.-Ing. Frank Mücklich, Saarland University and Dr. Abdallah Ababneh of the Micromechanics, Microfluidics and Microactuators Research Group for Sputtering equipment. Also, thanking for financial support as well as discussions with Prof. Frank Mücklich and Dr. H. A. Gobran by Central Metallurgical Research \& Development Institute- Tabin, Egypt.

\section{References:}

1. M. Wolff, JOM 1, 34 (1997).

2. S. Medeiros, F. Machado and L. Acioli, Ferroelectrics 305, 193 (2004).

3. D. Mandrus, V. Keppens, and B. C. Sales, Phys. Rev. B. 58, 3712 (1998).

4. R. Checchetto, C. Tosello1, A. Miotello1 and G. Principi, J. Phys.: Condens. Matter 13, 811 (2001).

5. R. W. Bene, App. Phys. Lett., 41, 529 (1982).

6. U. Rothhaar, H. Oechsner, M. Scheib, and R. Müller, Phys. Rev. B, 61(2), 974 (2000).

7. G. Colgan, M. Nastasi and J. W. Mayer, J. Appl. phys. 58, 4125 (1985).

8. G. Colgan, M. Nastasi, and J. W. Mayer, J. Appl. phys., 58, 4125 (1985).

9. R. Hultgren, P.D. Desai, D.T. Hawkins, M. Gleiter, K.K. Kelley, "Selected Values of the Thermodynamic Properties of Binary Alloys", Metals Park, OH: American Society for Metals, p. 156 (1973). 
10. A. Jeremy Walraven, 'Tools and Techniques for Failure Analysis and Qualification of MEMS' Itc Inter. Test Conf. IEEE, 834 (2003).

11. E. A. Kondrashkina, S. A. Stepanov, M. Schmidbauer, R. Opitz, and R. Koehler, H. Rhan, J. Appl. Phys. 81, 175 (1997).

12. Edshammar, Acta Chem. Scand. 20, 427 (1966).

13. A. Zariff Chaudhury, V. S.Gunturi Sastry and Challapalli Suryanarayana, Z. Metall. 73, H. 4 (1982).

14. Natl. Bur. Stand. [U.S.] Monogr., 25, 15, 84 (1978).

15. M. Zhang, M. Yu. Efremov, E. A. Olson, Z. S. Zhang, and L. H. Allen, Appl. Phys. Lett. 81, 3801 (2002).

16. A. N. Varich and R. B. Lyukevich, UDC 73 (1971).

17. L. F. Mondolfo, “Aluminum Alloys: Structure and Properties”, Butterworth \& Co Publishers, IX, p. 361 (1979).

18. C.V. Thompson, Annu. Rev. Mater. Sci. 30, 159 (2000). 
